\title{
Models and Mathematical Modelling: What Do Teachers and Preservice Teachers Know?
}

\author{
Yaşar, Akkan ${ }^{1, *}$, Mesut, Öztürk ${ }^{2}$, Pınar, Akkan ${ }^{3}$ \& Zafer, Çakır ${ }^{1}$ \\ ${ }^{1}$ Department of Mathematics Engineering, Gümüşhane University, Gümüşhane, Turkey \\ ${ }^{2}$ Department of Mathematics and Science Education, Bayburt University, Bayburt, Turkey \\ ${ }^{3}$ Mechatronics Department, Gümüşhane University, Gümüşhane, Turkey \\ *Correspondence: Faculty of Engineering and Natural Science, Department of Mathematics Engineering, \\ Gümüşhane University, Gümüşhane, Turkey. Tel: 90-533-646-8061. E-mail: akkanyasar61@hotmail.com
}

Received: June 5, 2018

Accepted: June 27, 2018 Online Published: August 6, 2018

doi:10.5430/jct.v7n2p33

URL: https://doi.org/10.5430/jct.v7n2p33

\begin{abstract}
The aim of the research is to examine the perspectives of teachers and preservice teachers in regard with models, mathematical models and mathematical modelling process in different variables terms and to compare them. In this research that is having quantitative research design survey method, which is one of the descriptive research technic, survey method is used. Research is performed with 127 teacher and preservice teachers. It is benefitted from a different survey in the stage of data collection and open ended questions that is developed by the researcher. In the analysis of the data, descriptive and inferential statistical methods and content analysis method were used. As a result, views of the teachers and preservice teachers regarding (mathematical) models and mathematical modelling shows differences according to some variables, however, it is not found out most significant differences in the views of the teachers and preservice teachers in regard with these subjects.
\end{abstract}

Keywords: models, modelling, mathematics education, teachers and preservice teachers

\section{Introduction}

Developing the main mathematical skills such as problem solving, connecting, reasoning and communication that are needed by individuals in our day is the requirement of age. Particularly individuals have to have skills to be able to model problems in order to solve the problems they face in their daily lives (Wood, 1992) and in gaining these skills by students, teachers have to use their knowledge and skills about model and modelling efficiently (Thomas \& Hart, 2010). Thus, in most of education systems in our days, model and modelling is mentioned (Blomhoj \& Kjeldsen, 2006; Chan, 2010; Lingefjärd, 2006; National Council of Teachers of Mathematics [NCTM], 2000; Peled, 2010; Turkish Ministry of Education [MEB], 2005). The need for individuals who are able to modelling mathematics and use it in problem solving is specified as general purpose in the Secondary Education Math Class Curriculum that is renewed in 2013 (MEB, 2013). Because in the connecting mathematics with the real life models and modelling are very important.

\subsection{Modelling}

Model that is an all of systems representing objects, facts and thoughts (Gilbert, Boulter \& Elmer, 2000), is a structure ensuring our understanding of bringing about of objects, their manners and their development processes as well as predicting about that (Harrison, 2001). Models that have a changeable structure are the dynamic patterns that can be changed by new information (Harrison, 2001; Justi \& Gilbert, 2002). Models cannot be an exact copy of reality as they are not able to reflect all properties of the reality and they also include additional explanations in addition to the target they represent (Gobert \& Buckley, 2000; Harrison, 2001; Örnek, 2008). Although Harrison and Treagust (2000) models scale, pedagogical and analogical, symbolical and symbolic theoretical, maps, diagrams and tables, concept-process, simulations, mental, synthetic models the classification that is gained acceptance in literature they are in the form of physical, analogical (descriptive, imaginary), symbolical (formal, digital) and theoretical models. On the other hand, modelling, which is a scientific study, is all of scientific operations used in the process of model creation (Justi \& Gilbert, 2002). In this context, it can be made out that the purpose of modelling is model 
creation, but this inference is not quite sufficient. Modelling process both includes states and events necessary for explanation by models and requires to use and interpret created models. In other words, the main purpose in modelling is not create model or models but to be able to make explanations for a state or event by aid of models (Bukova Güzel, 2016). In this sense, while model expresses created product in the end of process, modelling expresses physical, symbolical or abstract model (Lesh \& Doerr, 2003). In that case, models must be considered as products necessary for realization of modelling that is required to be reached in modelling process (Hıdıroğlu, 2012; Sriraman, 2005). One of the sub-concepts of modelling concept that is used in different spaces by different senses is mathematical modelling concept.

\subsection{Mathematical Modelling}

As mathematical modelling definitions/approaches are based on quite different theoretical bases (Kaiser, Blomhøj \& Sriraman, 2006), it is not possible to give a single definition that is accepted in all world literature related to mathematical modelling. Mathematical modelling, as different from other modelling types, explains a process, in which mathematical symbols, concepts and skills are set to work, where real living and mathematics are linked with each other (Bukova Güzel, 2016). Mathematical modelling, which in the most general sense is a process where the real life state is transferred into mathematical language and specified as mathematical (Berry \& Houston, 1995) which is being defined as expressing an event that is mathematical or out of mathematical, a fact, relations between events in mathematical language and bringing mathematical patterns out from events and facts (Verschaffel, Greer \& De Corte, 2002). On the other hand, Lesh and Doerr (2003) expresses the mathematical model as external representations, which is transformed by mental constructs providing an opportunity to mathematical model to interpret and analyse a real state. According to MEB'e (2005), while mathematical model is a work to bring the exiting states out by gathering mathematical statements, forms and concepts, mathematical modelling is a dynamic method by which we see, express, classify, generalize and easily draw a conclusion on the real life problems. However, mathematical modelling process, which is including much more than forming model for explaining a problem state, has a complex structure (Lingefjärd, 2006). Lesh and Doerr (2003) designates all mental instruments used by the students in the mathematical modelling process as mental models and defines the mathematical modelling process as a process requiring mathematical modelling process. For this reason, another concept that has to be laid emphasis on is mathematical modelling process.

When the studies are examined different modelling processes are attracted attention and this difference is considered linking with the interpretation made by the researches about modelling and the structure of the problems (Borromeo Ferri, 2006). In the researches related mathematical modelling process generally it is aimed to reveal mental activities forming mathematical modelling process and to explain transitions and relations between mental activities. One of the original researches in body of literature Kapur (1982) described the mathematical modelling process as selecting convenient variables, as revealing connection between variables, as producing a mathematical model including variables and connections, and to test the model and its practices. Afterwards, Müller and Witmann (1984) underlined that modelling process is formed by three main steps - setting up model, processing data in the model and interpretation. On the other hand, Mason (1988) expressed the modelling process with the following steps: The real living problems are formulated by mathematical symbols, revealing mathematical model from the variables describing states and equations related to these variables, interpreting and explaining mathematical results gained from analysed problems in the scope of real living state. Berry and Houston (1995), remarked that process is realized by the interaction between the real life and mathematical world. It is required to switch to mathematics for formulating the real living state and it is required to switch to the real life again for interpreting mathematical results that have been gained. On the other hand, Berry and Davies (1996) approached the mathematical modelling circle in seven main steps, namely, real life problem state, formulating the model, analysis mathematically, interpreting analysis, evaluation the solution, revising the model and report. Cheng (2001) explained mathematical modelling as an intense interaction process between the real life and mathematical world and described the main components in mathematical modelling process as the real living problem (the real life solution), mathematical problem as making hypothesis, formulating equation (formulating the model), solving the equation, interpreting solution, comparing the data (comparing the real life solution with solvation gained by model), interpreting the model and revise the model. Borromeo Ferri (2006) expressed that mathematical modelling process circle comprises six circles, namely, understanding the problem, simplification the problem, making the problem mathematical, to study mathematically, interpreting and verification. In an another process research Voskoglou (2006), approached the mathematical modelling process in five main steps, namely, analysis of the problem, making the problem mathematical, solving the model, verification of model, interpreting the results and specified that it is possible to switch to in between every steps in the process, and this state makes the solving process complicated. On the other hand, in the studies where the 
impact of technology upon mathematical modelling process is examined different modelling processes draw attention. Galbraith and Stillman (2006) described components of mathematical modelling process supported by technology, as complicated real living state, real life problem state, mathematical model, mathematical solving, real life meaning of the solution, revising the model or acceptance of solution, report. Hidıroğlu (2012), by aiming to reveal cognitive activities in mathematical modelling process supported by technology described eight main components - complicated real life state, real life problem state, model of real life problem state, auxiliary mathematical models, main mathematical models, mathematical solution, real life solution, short solution report and as well as he described seven main steps providing passing between the components - analysis of problem, setting up systemically structure, making it mathematical, making it upper mathematical, mathematical analysis, interpretation/evaluation, verification of the model.

In the end of literature review it is understood that researches about model and modelling have been performed mostly with teachers, preservice teachers and students. The studies that has been made related teachers are in general descriptive researches to reveal especially the knowledge and views of the teachers in different branches, particularly science teachers (Akgün, Çiltaş, Deniz, Çitfçi \& Iş̧k, 2013; Ergin, Özcan \& Sarı, 2012; Günbatar \& Sarı, 2005; Justi \& Gilbert, 2003; Marquez, Izquierdo \& Espinet, 2006; Van Driel \& Verloop,1999). The researches indicate that teachers use models in the teaching of any concept, but they have insufficient knowledge about representation and prediction characteristics of the model. The studies that have been made with preservice teachers revealed that their knowledge about models and modelling are insufficient and complicated (Berber \& Güzel, 2009; Danusso, Testa \& Vicentini, 2010; Everett, Otto \& Luera, 2009; Güneş; Bağçı \& Gülçiçek, 2004; Justi \& Gilbert, 2002; Shen \& Confrey, 2007; Smit \& Finegold, 1995). On the other hand, researches that have been made with their students are mostly related to the impact on student success and model usage in training (Acher, Arca \& Sanmarti, 2007; Çökelez, 2009; Gobert, 2000; Grosslight, Unger, Jay \& Smith, 1991; Gümüş, Demir, Koçak, Kaya \& Kırıc1, 2008; Maia \& Justi, 2009; Marquez et al., 2006; Rotbain, Marbach-Ad \& Stavy, 2006; Taylor, Barker \& Jones, 2003). On the other hand, in the studies that have been made in level of university there are also researches revealing insufficient knowledge of students about models and modelling (Coll \& Treagust, 2003; Danusso et al., 2010). Although one of the subjects most debated in mathematical training is mathematical models and modelling it has been found out that the quantitative researches related to this field are insufficient. However, mathematical model and modelling is not placed emphasis by many people related to training and have not been practiced (Blum \& Feri, 2009). One of the factors related to this is the difficulty of mathematical modelling process having many components for the individuals. Whereas, the view that (mathematical) model and modelling have to form important part of mathematical classes from elementary schools to higher schools has been emphasized in the last years and the hypothesis that mathematic would be aid for students to understand the real life and the requirement of using modelling in mathematical training has been the main ground (Erbaş et al., 2014; MEB, 2005, 2013; NCTM, 1989, 2000). Thus, by the researches it has been revealed that students need guidance of their teachers to use models (Treagust, 2002), that the teachers have been more efficient in the learning of students about scopes and limitations of models significantly (Gödek, 2004), that concrete models have auxiliary impacts on learning (Treagust et al., 2002), that models contribute to the problem solving skills of students (English, 2006; O'Connell \& San Giovanni, 2013), that usage of model and modelling are the most important activity for students in setting up hypothesis and symphonizing (Lee, Jonassen \& Teo, 2011). In this content, it is necessary for the teachers and preservice teachers to have sufficient knowledge about (mathematical) model and modelling. This survey study has been designed to provide a distinguishing perspective of the teachers and preservice teachers about models, mathematical models, and mathematical modelling.

Aim of this study is to examine and compare the perspectives of teachers (secondary school and high school) and preservice teachers (elementary mathematics preservice teachers) about models, mathematical modelling process and mathematical models in terms of different variables. In this purpose scope answers have been searched for the following problems:

1. Does the perspectives of teachers and preservice teachers about models, mathematical models and mathematical modelling process differ from according to the different variables (gender, age, experience year, school type where they work, class level)?

2. Does the perspectives of teachers and preservice teachers about models, mathematical models and mathematical modelling process differ from each other?

3. What is the reason of teachers and preservice teacher's perspectives benefitting from mathematical models, mathematical modelling, mathematical modelling process and mathematical modelling? 


\section{Method}

\subsection{Research Design}

Research has the quantitative searching design. In the research survey method from the descriptive searching methods is used (Cohen, Manion \& Morrison, 2000). Descriptive researches is generally used to explain a given state and evaluate it and to reveal the potential relations between the facts (Çepni, 2007). Survey method is used in larger field and not experimental. It is used as an information collection method by taking view from a sample about the mentioned state (Christensen, 2004).

\subsection{Sampling}

Research has been made in three provinces being in the Eastern Blacksea and Northeastern Anatolia regions in Turkey. The sample of the research is consisting of 127 teachers and preservice teachers. The teachers being in this sample are mathematics teachers in the high schools and secondary schools. The preservice teachers are the students educating 3. and 4. class in the elementary mathematics teaching. In sample selection convenient sampling method from the non-probability sampling methods. In the selection convenient sample method, it has been paid regard to the easiness and accessibility of the individuals or the groups to be participated in the research practice (Johnson \& Christensen, 2004). Personal properties of the participants are placed in Table 1.

Table 1. Personal Properties of the Participants

\begin{tabular}{|c|c|c|c|c|c|}
\hline \multicolumn{3}{|c|}{ Personal properties of the teachers } & \multicolumn{3}{|c|}{ Personal properties of preservice teachers } \\
\hline Variables & Categories & $\mathrm{n}$ & Variables & Categories & $\mathrm{n}$ \\
\hline \multirow[t]{2}{*}{ Gender } & Male & 29 & Gender & Male & 29 \\
\hline & Female & 34 & & Female & 35 \\
\hline \multirow[t]{3}{*}{ Age } & $\ldots \leq 29$ age and lower & 21 & Class level & 3.class & 29 \\
\hline & 30 age $\leq \ldots \leq 39$ age & 23 & & 4.class & 35 \\
\hline & $\ldots \geq 40$ age and upper & 19 & & & \\
\hline Experience & $\ldots \leq 2$ year and lower & 19 & & & \\
\hline \multirow[t]{2}{*}{ year } & 3 year $\leq \ldots \leq 5$ year & 20 & & & \\
\hline & $\ldots \geq 6$ years and upper & 24 & & & \\
\hline \multirow[t]{2}{*}{ School type } & Secondary school & 32 & & & \\
\hline & High school & 31 & & & \\
\hline
\end{tabular}

\subsection{Data Collection Instruments}

In the study it has been benefitted from two different surveys (Gould, 2013; Güneş et al., 2004; Treagust, 2002) and the survey questions developed by the researcher and a survey has been set up convenient to the purpose of the study. The first section of the survey has been designed to reveal the personal information of teachers and preservice teachers. In the second section it has been benefitted from the survey adapted from Treagust (2002) by Güneş et al. (2004) in order to specify the views of teachers and preservice teachers generally in models. The survey that is consisted with 30 items has been set up by six dimensions as Models as Multiple Representations (MMR), Models as Exact Replicas (MER), Models as Explanatory Tools (MET), The Uses of Scientific Models (USM), The Changing Nature of Models (CNM) and Model Samples (MS).

The third section is consisted with 15 items. 14 items of the section are originally developed by Gould (2013) to take the views of mathematics teachers about mathematical modelling and afterwards Golden (2013) used the survey on the purpose of comparing the mathematical modelling knowledge of the elementary school teachers and preservice teachers. An item in this section as "Mathematical models may be virtual manipulative -for example, like learning objects...) is added by the researchers to this survey. This section of the survey consists 7 items related Mathematical Models (MM) and 8 items related Mathematical Modelling Process (MMP). After necessary permissions have been received "English-Turkish Accordance and Turkish Intelligibility Rating Forms" have been used for the survey in this section and required changes have been made on the items by paying regard to the both language experts suggestions. In this context, the process related rating forms are as follow: The items of the original survey which is written in English is placed on the left side, their Turkish translations is placed on the right side and the rating space from 0 to 10 specifying accordance rating is placed on the middle side. The literature experts (who are working in education sector, three academicians who know very well English language) are required to read the original item of the survey and then the Turkish translation corresponding to the same item and to make an evaluation to find out if 
the translation is convenient or not in terms of meaning. In this rating expert is asked to give zero (0) points if the translation is not corresponding to the original, to give ten (10) points if it is completely corresponding to the original. On the other hand, experts are asked when they are making rating to specify their suggestions related to spelling on account of translation items is bound to the English originals and some changes has been made on the Turkish translations items. Afterward, the two Turkish Language and Literature experts are asked to point the Turkish linguistics accordance and intelligibility levels in terms of Turkish language rules (in the way if they are not intelligible zero 0 , if they are intelligible completely 10 and to specify their suggestions. By paying regard to the suggestions made by the language experts necessary changes have been made on the items and, in this way, it has been tried to realize the validity of the third section of the survey on the terms of translation and language. Afterwards, it has been applied to the views of three experts for the items of the survey and after the items have been examined it has been decided that the research is convenient to the purpose and consisted the subject of the research. In the fourth section of the survey five open ended questions developed by the researches in literature support are placed. These questions are as follow: According to you what is mathematical modelling. Please identify...According to you what are the properties of mathematical modelling? Please explain...According to you what can be a mathematical model) Please explain...According to you what is mathematical modelling process? What are the stages of the process? Please explain. Would you like to be benefitted from mathematical modelling? (If yes) Why are you benefitted from it? (If no) Why you are not being willing to be benefitted from it?

\subsection{Data Analysis}

In data analysis, we used descriptive and inferential statistical methods. As descriptive, in order to specify levels of the views of the teachers and preservice teachers about model, modelling, mathematical models and mathematical modelling process arithmetic average and Standard deviation values of the points gained from the scales have been benefitted. In the specifying and interpreting of the views of teachers and preservice teachers about models, mathematical models and mathematical modelling process for providing the standard average range "1.00-1.80: Strongly Disagree $\left(\mathrm{SD}^{-}\right)$; 1.81-2.60: A little Disagree (D); 2.61-3.40: Undecided (Neither agree nor disagree) $\left(\mathrm{U}^{0}\right)$; 3.41- 4.20: A little Agree ( $\left.\mathrm{A}^{+}\right)$and 4.21- 5.00: Strongly Agree (SA ${ }^{+}$") is used. It has been supposed that ranges are equal and for arithmetic averages the point range 0,80 has been calculated (Point range $=$ (The highest value Lowest value) $/ 5=(5-4) / 5=4 / 5=0.80)$. On the other hand, in testing to find out whether there is a difference between the views of teachers and preservice teachers about models, mathematical models and mathematical modelling process as statistical or not it has been benefitted from independent group t-test and an one-way analysis of variance (ANOVA). In the analysis of the data gained from the research SPSS 20.0 packaged software has been used. On the other hand, in evaluation of data gained from the open ended questions both frequency and percent value and content analysis method have been used (Yıldırım \& Şimşek, 2005), codes have been created and interpreted.

\section{Results}

In this section analysis results related each problem of the research are presented with tables and interpretations are made related tables.

3.1 First Problem: Are the views of the teachers and preservice teachers about (mathematical) models and mathematical modelling process differ according to the different variables (gender, age, experience year school type where perform duty, class level)?

The views of the teachers and preservice teachers about models, mathematical models and mathematical modelling process is analysed according to the variables of gender, age, experience year, type of school and class level and the gained findings are presented respectively.

\subsection{According to the Gender of Teachers}

Whether there is a significant difference between the views of teachers according to gender variable or not is analysed by t-test for independent groups and the results are given in the Table 2 .

According to the t-test results in Table 2, between the views of male and female mathematics teachers about usage of more than one model in order to find out the different angles of models as multi representations namely a scientific event, concept or process $(t=5.853 ; \mathrm{p}<.05)$, views about the participation of model in finding out of any fact $(\mathrm{t}=$ 9.890; $\mathrm{p}<.05)$, their understandings about how the models are used except of descriptive and explanatory $(\mathrm{t}=4.236$; $\mathrm{p}<.05)$ and their views about the permanence (continuity) of models $(t=5.875 ; \mathrm{p}<.05)$ differences have been found out significantly and it has been found out that all of these differences are on behalf of female teachers. 
However, according to the results of t-test it has been found out that the perception about a model how much can be similar to the object $(\mathrm{t}=.884 ; \mathrm{p}>.05)$ and their views about the model samples used $(\mathrm{t}=.111 ; \mathrm{p}>.05)$ it has been found out that there is no any significant difference. In similar way, according to the t-test between the views of male and female teachers about both mathematical models $(t=1.806 ; \mathrm{p}>.05)$ and mathematical modelling process $(\mathrm{t}$ $=.400 ; \mathrm{p}>.05)$ it has been found out that there is no any significant difference statistically.

Table 2. Results of Independent Group T-Test According to the Gender of Teachers

\begin{tabular}{|c|c|c|c|c|c|c|c|}
\hline Survey & Components & Gender & $\mathrm{n}$ & $\bar{x}$ & $\mathrm{sd}$ & $\mathrm{t}$ & $\mathrm{p}$ \\
\hline \multirow{12}{*}{ Models } & \multirow{2}{*}{ MMR } & Male & 29 & 24.7931 & 7.12330 & \multirow{2}{*}{5.853} & \multirow{2}{*}{$.019 *$} \\
\hline & & Female & 34 & 28.5294 & 5.09447 & & \\
\hline & \multirow{2}{*}{ MER } & Male & 29 & 23.2069 & 7.48035 & \multirow{2}{*}{.884} & \multirow{2}{*}{.351} \\
\hline & & Female & 34 & 24.9706 & 7.37105 & & \\
\hline & \multirow{2}{*}{ MET } & Male & 29 & 17.7931 & 5.37441 & \multirow{2}{*}{9.890} & \multirow{2}{*}{$.003 *$} \\
\hline & & Female & 34 & 21.2647 & 3.27811 & & \\
\hline & \multirow{2}{*}{ USM } & Male & 29 & 10.2069 & 3.51912 & \multirow{2}{*}{4.236} & \multirow{2}{*}{$.044^{*}$} \\
\hline & & Female & 34 & 11.7647 & 2.46255 & & \\
\hline & \multirow{2}{*}{ CNM } & Male & 29 & 10.1379 & 3.47156 & \multirow{2}{*}{5.875} & \multirow{2}{*}{$.018^{*}$} \\
\hline & & Female & 34 & 12.0000 & 2.61696 & & \\
\hline & \multirow[b]{2}{*}{ MS } & Male & 29 & 13.1379 & 4.19799 & \multirow[b]{2}{*}{.111} & \multirow[b]{2}{*}{.741} \\
\hline & & Female & 34 & 14.7353 & 3.58709 & & \\
\hline \multirow{4}{*}{$\begin{array}{l}\text { Mathematical models } \\
\text { and modelling process }\end{array}$} & \multirow{2}{*}{ MM } & Male & 29 & 24.2759 & 7.83717 & \multirow{2}{*}{1.806} & \multirow{2}{*}{.184} \\
\hline & & Female & 34 & 26.3824 & 4.35552 & & \\
\hline & \multirow{2}{*}{ MMP } & Male & 29 & 31.3793 & 10.89696 & \multirow{2}{*}{.400} & \multirow{2}{*}{.530} \\
\hline & & Female & 34 & 32.7647 & 6.17943 & & \\
\hline
\end{tabular}

\subsection{According to the Ages of Teachers}

Whether there is a difference in the views of teachers in three different age groups about models, mathematical models and mathematical modelling process as being significant statistically or not has been tested according to one-way variance test (ANOVA) and presented in Table 3:

Table 3. One-Way Variance Analysis Results (ANOVA) According to the Ages of Teachers

\begin{tabular}{|c|c|c|c|c|c|c|c|}
\hline Survey & Components & & Total Squares & $\mathrm{df}$ & Mean Square & $\mathrm{F}$ & $\mathrm{p}$ \\
\hline \multirow{18}{*}{ Models } & \multirow{3}{*}{ MMR } & Between Groups & 106.171 & 2 & 53.085 & & \\
\hline & & Within Groups & 2389.544 & 60 & 39.826 & 1.333 & .271 \\
\hline & & Total & 2495.714 & 62 & & \multirow{4}{*}{.785} & \multirow{4}{*}{.461} \\
\hline & \multirow{3}{*}{ MER } & Between Groups & 86.880 & 2 & 43.440 & & \\
\hline & & Within Groups & 3321.533 & 60 & 55.359 & & \\
\hline & & Total & 3408.413 & 62 & & & \\
\hline & \multirow{3}{*}{ MET } & Between Groups & 31.679 & 2 & 15.840 & \multirow{3}{*}{.720} & \multirow{3}{*}{.491} \\
\hline & & Within Groups & 1320.321 & 60 & 22.005 & & \\
\hline & & Total & 1352.000 & 62 & & & \\
\hline & \multirow{3}{*}{ USM } & Between Groups & 5.289 & 2 & 2.645 & \multirow{3}{*}{.274} & \multirow{3}{*}{.761} \\
\hline & & Within Groups & 579.568 & 60 & 9.659 & & \\
\hline & & Total & 584.857 & 62 & & & \\
\hline & \multirow{3}{*}{ CNM } & Between Groups & 38.020 & 2 & 19.010 & \multirow{3}{*}{1.968} & \multirow{3}{*}{.149} \\
\hline & & Within Groups & 579.694 & 60 & 9.662 & & \\
\hline & & Total & 617.714 & 62 & & & \\
\hline & \multirow{3}{*}{ MS } & Between Groups & 41.003 & 2 & 20.501 & \multirow{3}{*}{1.341} & \multirow{3}{*}{.269} \\
\hline & & Within Groups & 916.997 & 60 & 15.283 & & \\
\hline & & Total & 958.000 & 62 & & & \\
\hline
\end{tabular}




\begin{tabular}{|c|c|c|c|c|c|c|c|}
\hline \multirow{6}{*}{$\begin{array}{l}\text { Mathematical models } \\
\text { and modelling process }\end{array}$} & \multirow{3}{*}{ MM } & Between Groups & 152.221 & 2 & 76.111 & \multirow{2}{*}{2.018} & \\
\hline & & Within Groups & 2263.049 & 60 & 37.717 & & 142 \\
\hline & & Total & 2415.270 & 62 & & & \\
\hline & \multirow{3}{*}{ MMP } & Between Groups & 86.360 & 2 & 43.180 & & \\
\hline & & Within Groups & 4528.624 & 60 & 75.477 & .572 & .567 \\
\hline & & Total & 4614.984 & 62 & & & \\
\hline
\end{tabular}

According to the results in Table 3 there is no significantly difference statistically in the following views of in different age group teachers about the models as being multi representations $\left(\mathrm{F}_{(2-62)}=1.333 ; \mathrm{p}>.05\right)$, their views related how a model is similar to the object represented by a model $\left(\mathrm{F}_{(2-62)}=.785 ; \mathrm{p}>.05\right)$, their views related to the contribution made by a model in understanding of any fact $\left(\mathrm{F}_{(2-62)}=.720 ; \mathrm{p}>.05\right)$, their views related how models can be used except for being descriptive and explanatory of models $\left(\mathrm{F}_{(2-62)}=.274 ; \mathrm{p}>.05\right)$, their views related permanence (continuity) of the models $\left(\mathrm{F}_{(2-62)}=1,968 ; \mathrm{p}>, 05\right)$, their views related used model samples $\left(\mathrm{F}_{(2-62)}=\right.$ $1.341 ; \mathrm{p}>.05$. Similarly, there has not been found out statistically any significant difference between both mathematical models $\left(\mathrm{F}_{(2-62)}=2.18 ; \mathrm{p}>.05\right)$ and mathematical modelling processes $\left(\mathrm{F}_{(2-62)}=.572 ; \mathrm{p}>.05\right)$.

\subsection{According to the Experience Years of the Teachers}

Whether there is a difference in the views of teachers according to the experience years about models, mathematical models and mathematical modelling process as being significant statistically or not has been tested according to one-way variance test (ANOVA) and presented in Table 4.

Table 4. One-Way Variance Analysis Results (ANOVA) According to the Ages of Teachers:

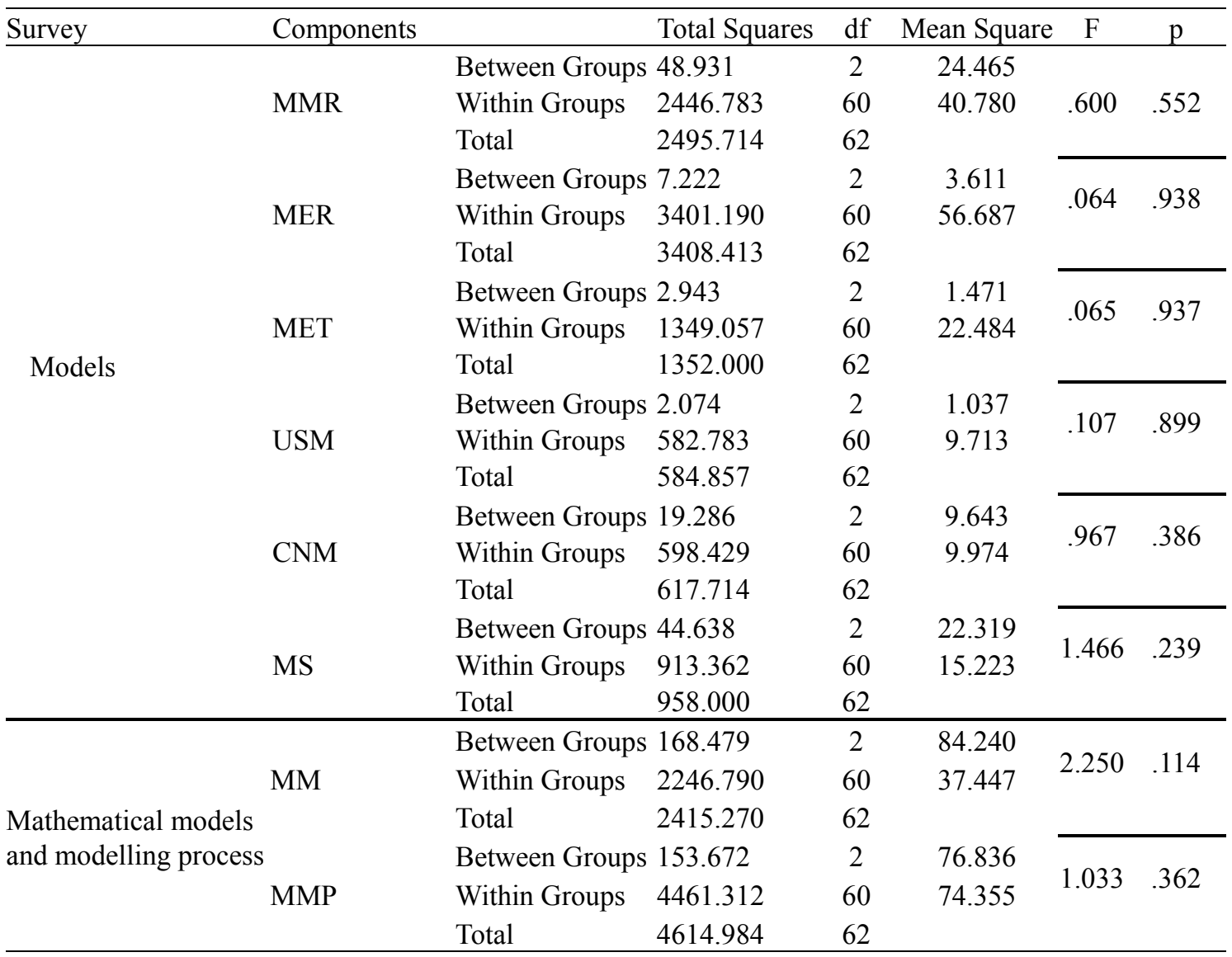

According to the results in Table 4 there is no significant difference statistically in the following views of in different mathematics teachers having three different experience year about the models as being multi representations $\left(\mathrm{F}_{(2-62)}\right.$ $=.600 ; \mathrm{p}>.05)$, their perceptions how much a model similar to an object for which it represents $\left(\mathrm{F}_{(2-62)}=.064\right.$; $\mathrm{p}>.05)$, their views about contribution made by the model in understanding any fact $\left(\mathrm{F}_{(2-62)}=.065 ; \mathrm{p}>.05\right)$, their 
views about how models can be used except for descripting and explanatory $\left(\mathrm{F}_{(2-62)}=.107 ; \mathrm{p}>.05\right)$, their views about permanence (continuity) of models $\left(\mathrm{F}_{(2-62)}=.967 ; \mathrm{p}>.05\right)$, their views about the used model samples $\left(\mathrm{F}_{(2-62)}=\right.$ $1.466 ; \mathrm{p}>.05)$.

\subsection{According to the School Types Where Teachers Work}

According to the independent groups t-test whether there is a significant difference between views about models, mathematical models and mathematical modelling process according to the school types where teachers work or not have been tested and presented in Table 5 .

Table 5. Independent Group-Test Results According to the School Type Where Teachers Work

\begin{tabular}{|c|c|c|c|c|c|c|c|}
\hline Survey & Component & School type & $\mathrm{n}$ & $\bar{x}$ & $\mathrm{sd}$ & $\mathrm{t}$ & $\mathrm{p}$ \\
\hline \multirow{12}{*}{ Models } & \multirow{2}{*}{ MMR } & Secondary school & 32 & 27.5938 & 5.06639 & \multirow{2}{*}{.993} & \multirow{2}{*}{.323} \\
\hline & & High school & 31 & 26.0000 & 7.43864 & & \\
\hline & \multirow{2}{*}{ MER } & Secondary school & 32 & 24.5938 & 8.37377 & \multirow{2}{*}{.221} & \multirow{2}{*}{.641} \\
\hline & & High school & 31 & 23.7097 & 6.38328 & & \\
\hline & \multirow{2}{*}{ MET } & Secondary school & 32 & 20.2188 & 3.82466 & \multirow{2}{*}{.908} & \multirow{2}{*}{.345} \\
\hline & & High school & 31 & 19.0968 & 5.41205 & & \\
\hline & \multirow{2}{*}{ USM } & Secondary school & 32 & 11.6563 & 2.82397 & \multirow{2}{*}{2.621} & \multirow{2}{*}{.111} \\
\hline & & High school & 31 & 10.4194 & 3.23290 & & \\
\hline & \multirow{2}{*}{ CNM } & Secondary school & 32 & 11.7500 & 2.94027 & \multirow{2}{*}{2.463} & \multirow{2}{*}{.122} \\
\hline & & High school & 31 & 10.5161 & 3.29516 & & \\
\hline & \multirow{2}{*}{ MS } & Secondary school & 32 & 15.0000 & 3.63673 & \multirow{2}{*}{4.442} & \multirow{2}{*}{$.039 *$} \\
\hline & & High school & 31 & 12.9677 & 4.01235 & & \\
\hline \multirow{4}{*}{$\begin{array}{l}\text { Mathematical models } \\
\text { and modelling process }\end{array}$} & \multirow{2}{*}{ MM } & Secondary school & 32 & 27.6250 & 4.54902 & \multirow{2}{*}{9.259} & \multirow{2}{*}{$.003 *$} \\
\hline & & High school & 31 & 23.1290 & 6.96535 & & \\
\hline & \multirow{2}{*}{ MN } & Secondary school & 32 & 34.2813 & 8.59195 & \multirow{2}{*}{4.268} & \multirow{2}{*}{$.043 *$} \\
\hline & & High school & 31 & 29.9032 & 8.21525 & & \\
\hline
\end{tabular}

According to the t-test results in Table 5 it has not been found out a significant difference between the views of secondary and high school teachers about models as being multi representation $(\mathrm{t}=.993 ; \mathrm{p}>.05)$, their perception about how much a model is similar to the object for which it represents $(t=.221 ; \mathrm{p}>.05)$, their views about contribution made by the model in understanding of any fact $(\mathrm{t}=.908 ; \mathrm{p}>.05)$, , their understandings about how the models can be used except for being descriptive and explanatory $(\mathrm{t}=2.621 ; \mathrm{p}>.05)$, their views about permanence (continuity) of the models $(\mathrm{t}=2.463 ; \mathrm{p}>.05)$. According to the $\mathrm{t}$-test results in Table 5 it has not been found out a significant difference between the views of secondary and high school teachers about models as being multi representation $(\mathrm{t}=.993 ; \mathrm{p}>.05)$, their perception about how much a model is similar to the object for which it represents $(\mathrm{t}=, 221 ; \mathrm{p}>, 05)$, their views about contribution made by the model in understanding of any fact $(\mathrm{t}=.908$; $\mathrm{p}>.05)$, their understandings about how the models can be used except for being descriptive and explanatory $(\mathrm{t}=$ $2.621 ; \mathrm{p}>.05)$, their views about permanence (continuity) of the models $(\mathrm{t}=2.463 ; \mathrm{p}>.05)$. However, a statistically significant difference was found between the views of the used model samples $(t=4.442 ; p<.05)$ and it was determined that the difference was in favour of the teachers working in secondary schools. Similarly, according to the table, it has been found out significant different statistically between the views of mathematics teachers working in two different school type about both mathematical models use $(\mathrm{t}=9.259 ; \mathrm{p}<.05)$ and mathematical modelling process $(\mathrm{t}=4.268 ; \mathrm{p}<.05)$ and it has been specified that these differences are on behalf of teachers who work in secondary schools.

\subsection{According to Genders of Preservice Teachers}

The views of the preservice teachers about models, mathematical models and mathematical modelling process is analysed by independent groups t-test to find out whether there is statistically significant difference and the results are presented in Table 6 . 
Table 6. Group-test Results According to the Gender of Preservice Teachers

\begin{tabular}{|c|c|c|c|c|c|c|c|}
\hline Survey & Components & Gender & $\mathrm{n}$ & $\bar{x}$ & $\mathrm{sd}$ & $\mathrm{t}$ & $\mathrm{p}$ \\
\hline \multirow{12}{*}{ Models } & \multirow{2}{*}{ MMR } & Male & 29 & 26.0000 & 3.60555 & \multirow{2}{*}{2.671} & \multirow{2}{*}{.107} \\
\hline & & Female & 35 & 26.0286 & 3.94436 & & \\
\hline & \multirow{2}{*}{ MER } & Male & 29 & 26.9655 & 5.05317 & \multirow{2}{*}{.023} & \multirow{2}{*}{.881} \\
\hline & & Female & 35 & 25.4000 & 5.15181 & & \\
\hline & \multirow{2}{*}{ MET } & Male & 29 & 18.9310 & 3.19521 & \multirow{2}{*}{1.247} & \multirow{2}{*}{.269} \\
\hline & & Female & 35 & 19.1429 & 2.90175 & & \\
\hline & \multirow{2}{*}{ USM } & Male & 29 & 10.5172 & 2.68089 & \multirow{2}{*}{2.611} & \multirow{2}{*}{.111} \\
\hline & & Female & 35 & 10.4857 & 2.59379 & & \\
\hline & \multirow{2}{*}{ CNM } & Male & 29 & 10.4483 & 2.06305 & \multirow{2}{*}{5.193} & \multirow{2}{*}{$.026^{*}$} \\
\hline & & Female & 35 & 10.9429 & 2.46078 & & \\
\hline & \multirow{2}{*}{ MS } & Male & 29 & 13.5862 & 2.99425 & \multirow{2}{*}{2.653} & \multirow{2}{*}{.108} \\
\hline & & Female & 35 & 14.2571 & 2.86298 & & \\
\hline \multirow{4}{*}{$\begin{array}{l}\text { Mathematical models } \\
\text { and modelling process }\end{array}$} & \multirow{2}{*}{ MM } & Male & 29 & 23.2414 & 3.12427 & \multirow{2}{*}{.005} & \multirow{2}{*}{.944} \\
\hline & & Female & 35 & 23.1143 & 3.66037 & & \\
\hline & \multirow{2}{*}{ MMP } & Male & 29 & 32.8966 & 5.86360 & \multirow{2}{*}{.000} & \multirow{2}{*}{.996} \\
\hline & & Female & 35 & 32.7714 & 6.14571 & & \\
\hline
\end{tabular}

Significant difference statistically about the views of male and female preservice teachers in Table 6 has not been specified in terms of multi representations models $(t=2.671 ; \mathrm{p}>.05)$, about perceptions how much a model is similar to the object which represents $(t=.023 ; \mathrm{p}>.05)$, their views related contribution made by the model in understanding of any fact $(t=1.247 ; p>.05)$, their views how the model can be used except for being descriptive and explanatory $(\mathrm{t}=2.611 ; \mathrm{p}>.05)$, their views about the model samples that are used $(\mathrm{t}=2.653 ; \mathrm{p}>.05)$. However, it has been found out a significant difference statistically about their views related permanence of the models $(\mathrm{t}=$ 5.193; $\mathrm{p}<.05)$, and it has been specified that this difference is on behalf of female preservice teachers. On the other hand, it has not been found out a significant difference in the views of male and female teachers about both mathematical models $(\mathrm{t}=.005 ; \mathrm{p}>.05)$ and the mathematical modelling process $(\mathrm{t}=.000 ; \mathrm{p}>.05)$.

\subsection{According to Class Levels}

Whether there is significant difference statistically according to class levels between the views of preservice teachers about models, mathematical models and mathematical process or not has been analysed by independent groups t-test and the results are presented in the Table 7.

Table 7. T-Test Results of the Preservice Teachers According to the Class Levels Where They Educate.

\begin{tabular}{|c|c|c|c|c|c|c|c|}
\hline Survey & Components & Class level & $\mathrm{n}$ & $\bar{x}$ & $\mathrm{sd}$ & $\mathrm{t}$ & $\mathrm{p}$ \\
\hline \multirow{12}{*}{ Models } & \multirow{2}{*}{ MMR } & 3.Class & 29 & 26.2414 & 4.31488 & \multirow{2}{*}{5.421} & \multirow{2}{*}{$.023^{*}$} \\
\hline & & 4. Class & 35 & 25.8286 & 3.29425 & & \\
\hline & \multirow{2}{*}{ MER } & 3. Class & 29 & 26.3448 & 4.65431 & \multirow{2}{*}{2.135} & \multirow{2}{*}{.149} \\
\hline & & 4. Class & 35 & 25.9143 & 5.54856 & & \\
\hline & \multirow{2}{*}{ MET } & 3. Class & 29 & 19.5517 & 2.87335 & \multirow{2}{*}{1.947} & \multirow{2}{*}{.168} \\
\hline & & 4. Class & 35 & 18.6286 & 3.10678 & & \\
\hline & \multirow{2}{*}{ USM } & 3. Class & 29 & 10.7586 & 2.97195 & \multirow{2}{*}{5.886} & \multirow{2}{*}{$.018^{*}$} \\
\hline & & 4. Class & 35 & 10.2857 & 2.29541 & & \\
\hline & \multirow{2}{*}{ CNM } & 3. Class & 29 & 10.5517 & 2.35412 & \multirow{2}{*}{2.509} & \multirow{2}{*}{.118} \\
\hline & & 4. Class & 35 & 10.8571 & 2.25105 & & \\
\hline & \multirow{2}{*}{ MS } & 3. Class & 29 & 14.4828 & 3.36601 & \multirow{2}{*}{2.435} & \multirow{2}{*}{.124} \\
\hline & & 4. Class & 35 & 13.5143 & 2.45395 & & \\
\hline \multirow{4}{*}{$\begin{array}{l}\text { Mathematical models } \\
\text { and modelling process }\end{array}$} & \multirow{2}{*}{ MM } & 3. Class & 29 & 23.7586 & 3.53205 & \multirow{2}{*}{1.728} & \multirow{2}{*}{.193} \\
\hline & & 4. Class & 35 & 22.6857 & 3.26092 & & \\
\hline & \multirow{2}{*}{ MMP } & 3. Class & 29 & 33.6207 & 6.34380 & \multirow{2}{*}{.009} & \multirow{2}{*}{.927} \\
\hline & & 4. Class & 35 & 32.1714 & 5.65418 & & \\
\hline
\end{tabular}


According to Table 7, it has not been found out a significant difference between views, and thoughts of 3.class and 4.class preservice teachers in terms of how much a model resembles the object which represent $(t=2.135 ; p>.05)$, about contribution that model made in understanding any fact $(\mathrm{t}=1.947 ; \mathrm{p}>.05)$, about permanence (continuity) $(\mathrm{t}=$ 2.509; $p>.05)$, about the model samples that have been used $(t=2.435 ; \mathrm{p}>.05)$. On the other hand, it has been found out a significant difference between their views about models as being multi representations $(t=5.421 ; p<.05)$ and their understandings about how models can be used except for being descriptive and explanatory $(\mathrm{t}=5.886 ; \mathrm{p}$ $<.05)$ and it has been found out that the differences are behalf of 3. Class preservice teachers. However, it has been found out that there is not significant difference statistically between 3.class preservice teachers and 4.class preservice teachers about both mathematical models $(\mathrm{t}=1.728 ; \mathrm{p}>.05)$ and mathematical modelling process $(\mathrm{t}$ $=.009 ; \mathrm{p}>.05)$.

\subsection{Second Problem: Is there any difference between the views of teachers and preservice teachers about (mathematical) models and mathematical modelling process?}

In this part, firstly the values about arithmetic averages $(\bar{x})$ and Standard deviations (ss) related views of teachers and preservice teachers about mathematical modelling process and mathematical models are given in Table 8 and Table 9 and afterwards they have been interpreted.

When Table 8 is examined it is found out that the teachers have been abstained or been irresolute in the last ten items of this survey. In general, it has been found out that teachers particularly have been irresolute and abstained in the dimensions whether how much a model resembles the object to which it represents and whether the given models are the model or not. Because, the arithmetic average values and the most of related evaluations consist the "I am disagreed" option. On the other hand, it may be said that the teachers are partly like - minded with the expressions related other dimensions. However, teachers are like - minded about the expressions related many models may be used in order to express properties of an event or properties of an object $(M=4,21 ; M=4,19)$. On the other hand, preservice teachers have been irresolte at the last twelve item of thirty item. The preservice teachers, just like teachers, have been irresolute in the subjects of to what extent a model resembles the object to which it represents and whether the given samples are model or not. On the other hand, the preservice teachers have been found out that they are in category of "I partly agree" in the subject of models as being multi representations, models as being explanatory instruments, use of scientific models and in the dimension of change of model structure. Particularly there have been found out no item on which preservice teachers are like minded. However, teachers and preservice teachers have been irresolute at the views of 'a model consists everything' about a model indicates or explains a scientific event $(M=2,77)$. They indicated that they are not aware of properties that are not shared as well as they are shared properties between models and the realities represented by the model. On the other hand, a significant part of teachers and preservice teachers are disagree that models have to be near to the reality they represent. Both teachers and preservice teachers, even if just a tad, are aware of the roles of models as being explanatory instruments. Because, average values belonging to five items in this dimension are, in general, changing between 3,73 and 4,17. Although it has been determined according to the average values that the teachers and preservice teachers have sufficient knowledge in the subject of why scientific models are used, it has been found out that the average value regarding the view which shows that "in order to show how models are used in scientific research again models are used", is close to the range of instability. This result is not compliance with the thought of Treagust (2002) to the effect that models are required to indicate how the models used in the research of models. On the other hand, the most part of teachers and preservice teachers adopt the views of models may be changed in direction of the new information gained. If we compare the values belong to the teachers and preservice teachers it is seen that participators in both groups are irresolute in the similar items namely it is seen similar distribution, that the preservice teachers generally are lower in arithmetic average values but there is no much difference between the values of both groups, that the teachers have better understanding than the preservice teachers even if just a tad but both groups have not sufficient knowledge about models. 
Table 8. Arithmetic Average and Standard Deviation Values Gained from Views of Teachers (T) and Preservice Teachers (PT) Related Models

Components / Items

M (sd)-Valuation

$\mathrm{T}$ PT

Many models may be used to express features of a science phenomenon by showing different perspectives to view an object

More than one models developed for a scientific phenomenon, represent different versions of the phenomenon

$\{\quad$ Models can show the relationship of ideas clearly

Many models may be used to show different sides or shapes of an object

Many models show different parts of an object or show the objects differently

Many models show how different information is used

A model has what is needed to show or explain a scientific phenomenon

A model should be an exact replica

A model needs to be close to the real thing

A model needs to be close to the real thing by being very exact, so nobody can disprove it

$\simeq \quad$ Everything about a model should be able to tell what it represents

$\sum \quad$ A model needs to be close to the real thing by being very exact in every way except for size

A model needs to be close to the real thing by giving the correct information and showing what the object/thing looks like

A model shows what the real thing does and what it looks like

Models show a smaller scale size of something

Models are used to physically or visually represent something

Models help create a picture in your mind of the scientific happening

$\stackrel{5}{\Sigma} \quad$ Models are used to explain scientific phenomena

Models are used to show an idea

A model can be a diagram or a picture, a map, graph or a photo

Models are used to help formulate ideas and theories about scientific

\section{$\sum_{n} \quad$ events}

Models are used to show how they are used in scientific investigations

Models are used to make and test predictions about a scientific event

A model can change if new theories or evidence prove otherwise

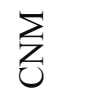

A model can change if there are new findings

A model can change if there are changes in data or belief

Models are used when theory is created

Table, formula, chemical symbol or schedule is a model

$\sum_{\Sigma}^{n} \quad$ Mock-up or a toy is model

Newton Laws, Archimedean Principle, Evolutionary Theory and Pythagoras' Theorem is model

\begin{tabular}{|c|c|}
\hline $4.21(1.1)-\mathrm{SA}^{+}$ & $4.00(0.9)-\mathrm{A}^{+}$ \\
\hline $3.95(1.1)-\mathrm{A}^{+}$ & $3.80(0.8)-\mathrm{A}^{+}$ \\
\hline $3.94(1.2)-\mathrm{A}^{+}$ & $3.84(0.8)-\mathrm{A}^{+}$ \\
\hline $4.19(1.2)-\mathrm{A}^{+}$ & $4.19(0.8)-\mathrm{A}^{+}$ \\
\hline $3.83(1.3)-\mathrm{A}^{+}$ & $3.70(0.9)-\mathrm{A}^{+}$ \\
\hline $3.98(1.3)-\mathrm{A}^{+}$ & $3.60(1.1)-\mathrm{A}^{+}$ \\
\hline $2.77(1.2)-\mathrm{U}^{0}$ & $2.75(1.0)-\mathrm{U}^{0}$ \\
\hline $2.04(1.1)-\mathrm{D}^{-}$ & $2.33(1.2)-\mathrm{D}^{-}$ \\
\hline $3.01(1.3)-\mathrm{U}^{0}$ & $3.33(1.1)-\mathrm{U}^{0}$ \\
\hline $2.60(1.1)-\mathrm{U}^{0}$ & $3.22(1.1)-\mathrm{U}^{0}$ \\
\hline $3.63(1.4)-\mathrm{A}^{+}$ & $3.70(0.9)-\mathrm{A}^{+}$ \\
\hline $2.89(1.2)-\mathrm{U}^{0}$ & $3.17(1.1)-\mathrm{U}^{0}$ \\
\hline $3.39(1.4)-\mathrm{U}^{0}$ & $3.38(1.1)-\mathrm{U}^{0}$ \\
\hline $3.39(1.3)-\mathrm{U}^{0}$ & $3.40(1.1)-\mathrm{U}^{0}$ \\
\hline $3.11(1.3)-\mathrm{U}^{0}$ & $3.30(1.2)-\mathrm{U}^{0}$ \\
\hline $3.93(1.2)-\mathrm{A}^{+}$ & $3.84(1.0)-\mathrm{A}^{+}$ \\
\hline $4.03(1.2)-\mathrm{A}^{+}$ & $4.03(0.8)-\mathrm{A}^{+}$ \\
\hline $3.73(1.2)-\mathrm{A}^{+}$ & $3.73(0.8)-\mathrm{A}^{+}$ \\
\hline $3.79(1.1)-\mathrm{A}^{+}$ & $3.50(1.0)-\mathrm{A}^{+}$ \\
\hline $4.17(0.9)-\mathrm{A}^{+}$ & $3.82(.08)-\mathrm{A}^{+}$ \\
\hline $3.86(1.2)-\mathrm{A}^{+}$ & $3.62(1.0)-\mathrm{A}^{+}$ \\
\hline $3.54(1.1)-\mathrm{A}^{+}$ & $3.48(1.0)-\mathrm{A}^{+}$ \\
\hline $3.65(1.2)-\mathrm{A}^{+}$ & $3.39(1.1)-\mathrm{U}^{0}$ \\
\hline $3.68(1.2)-\mathrm{A}^{+}$ & $3.60(0.9)-\mathrm{A}^{+}$ \\
\hline $3.84(1.2)-\mathrm{A}^{+}$ & $3.69(0.9)-\mathrm{A}^{+}$ \\
\hline $3.62(1.2)-\mathrm{A}^{+}$ & $3.33(1.1)-\mathrm{U}^{0}$ \\
\hline $3.40(1.2)-\mathrm{U}^{0}$ & $3.33(1.1)-\mathrm{U}^{0}$ \\
\hline $3.39(1.4)-\mathrm{U}^{0}$ & $3.38(1.2)-\mathrm{U}^{0}$ \\
\hline $3.98(1.1)-\mathrm{A}^{+}$ & $3.99(1.0)-\mathrm{A}^{+}$ \\
\hline $3.10(1.5)-\mathrm{U}^{0}$ & $3.22(1.0)-\mathrm{U}^{0}$ \\
\hline
\end{tabular}


Table 9. Arithmetic Average and standard Deviation Values Gained from the Views of Teachers and Preservice Teachers Related Mathematical Models and Modelling Process

\begin{tabular}{|c|c|c|c|c|c|}
\hline \multirow{2}{*}{\multicolumn{2}{|c|}{ Components/Items }} & \multicolumn{2}{|l|}{$\mathrm{T}$} & \multicolumn{2}{|l|}{$\mathrm{PT}$} \\
\hline & & M (sd)-Valuation & No idea & M (sd)-Valuation & No idea \\
\hline \multirow{7}{*}{$\sum$} & $\begin{array}{l}\text { Mathematical models can be physical } \\
\text { manipulatives (fraction tiles, pattern } \\
\text { blocks, or three-dimensional solids) }\end{array}$ & $4.00(1.8)-\mathrm{A}^{+}$ & $7(\% 11)$ & $3.84(1.5)-\mathrm{A}^{+}$ & $7(\% 11)$ \\
\hline & $\begin{array}{l}\text { Mathematical models may be virtual } \\
\text { manipulatives (learning objects) }\end{array}$ & $3.40(1.8)-\mathrm{U}^{0}$ & $14(\% 22)$ & $3.38(1.5)-\mathrm{U}^{0}$ & $10(\% 16)$ \\
\hline & $\begin{array}{l}\text { Mathematical models can be visual } \\
\text { representations such as a graph in the } \\
\text { Cartesian plane or the real number line }\end{array}$ & $3.90(1.8)-\mathrm{A}^{+}$ & $7(\% 11)$ & $3.84(1.5)-\mathrm{A}^{+}$ & $7(\% 11)$ \\
\hline & $\begin{array}{l}\text { Mathematical models can be equations } \\
\text { or formulas, for example, a quadratic } \\
\text { equation or the distance-rate formula }\end{array}$ & $3.30(1.8)-\mathrm{U}^{0}$ & $7(\% 11)$ & $2.72(1.7)-\mathrm{U}^{0}$ & $9(\% 14)$ \\
\hline & $\begin{array}{l}\text { Mathematical models can be visual } \\
\text { representations such as a scaled map of } \\
\text { the county or an architectural blueprint }\end{array}$ & $3.30(1.9)-\mathrm{U}^{0}$ & $15(\% 24)$ & $3.27(1.5)-\mathrm{U}^{0}$ & $17(\% 27)$ \\
\hline & $\begin{array}{l}\text { Mathematical models can be used to } \\
\text { describe or summarize a given situation } \\
\text { in a compact form }\end{array}$ & $3.90(1.9)-\mathrm{A}^{+}$ & $8(\% 13)$ & $3.70(1.5)-\mathrm{A}^{+}$ & $7(\% 11)$ \\
\hline & $\begin{array}{l}\text { Mathematical models can be used to } \\
\text { explain the underlying causes in a given } \\
\text { situation }\end{array}$ & $3.50(1.7)-\mathrm{A}^{+}$ & $6(\% 10)$ & $2.95(1.7)-\mathrm{U}^{0}$ & $10(\% 16)$ \\
\hline \multirow{8}{*}{$\sum_{\sum}^{Q}$} & $\begin{array}{l}\text { Repeating steps is part of the } \\
\text { mathematical modelling process }\end{array}$ & $3.20(1.7)-\mathrm{U}^{0}$ & $6(\% 10)$ & $2.89(1.7)-\mathrm{U}^{0}$ & $12(\% 19)$ \\
\hline & $\begin{array}{l}\text { Mathematical modelling situations come } \\
\text { from "whimsical" or unrealistic } \\
\text { scenarios }\end{array}$ & $1.50(1.0)-\mathrm{SD}^{-}$ & $10(\% 16)$ & $2.61(1.6)-\mathrm{U}^{0}$ & $7(\% 11)$ \\
\hline & $\begin{array}{l}\text { The mathematical modelling process } \\
\text { involves making choices }\end{array}$ & $3.00(1.4)-\mathrm{U}^{0}$ & $4(\% 6)$ & $2.89(1.7)-\mathrm{U}^{0}$ & $10(\% 16)$ \\
\hline & $\begin{array}{l}\text { The mathematical modelling process } \\
\text { involves making assumptions }\end{array}$ & $2.90(1.5)-\mathrm{U}^{0}$ & $6(\% 10)$ & $2.97(1.6)-\mathrm{U}^{0}$ & $10(\% 16)$ \\
\hline & $\begin{array}{l}\text { The mathematical modelling process } \\
\text { involves determining if a solution makes } \\
\text { sense in terms of the original situation }\end{array}$ & $3.60(1.5)-\mathrm{A}^{+}$ & $2(\% 3)$ & $3.50(1.6)-\mathrm{U}^{0}$ & $8(\% 13)$ \\
\hline & $\begin{array}{l}\text { The mathematical modelling process } \\
\text { involves making revisions }\end{array}$ & $3.60(1.7)-\mathrm{A}^{+}$ & $5(\% 8)$ & $3.30(1.8)-\mathrm{U}^{0}$ & $10(\% 16)$ \\
\hline & $\begin{array}{l}\text { The mathematical modelling process } \\
\text { results in an exact answer or exact } \\
\text { answers }\end{array}$ & $3.20(1.6)-\mathrm{U}^{0}$ & $3(\% 5)$ & $3.10(1.5)-\mathrm{U}^{0}$ & $8(\% 13)$ \\
\hline & $\begin{array}{l}\text { A mathematical modelling situation can } \\
\text { result in various, different mathematical } \\
\text { models }\end{array}$ & $3.40(1.6)-\mathrm{U}^{0}$ & $6(\% 10)$ & $3.38(1.5)-\mathrm{U}^{0}$ & $10(\% 16)$ \\
\hline
\end{tabular}

When Table 9 is examined it has been found out that teachers are in general irresolute about mathematical models and mathematical modelling views. Teachers opine that physical manipulatives may be mathematical models $(\mathrm{M}=4,00)$ but they have been irresolte about visual presentations ,(maps, scales etc.) may be mathematical models $(\mathrm{M}=3,20)$. Thus, number of teachers who have not opined that visual presentations (maps, scales etc.)may be mathematical models is $15(24 \%)$. Similarly, teachers have been irresolute in seven item of eight item related mathematical modelling process. On the other hand, there are also teachers who have not opined about items namely 
teachers who have said "I do not know or I have no idea" and percentage of these teachers are changed between 3\% and $24 \%$. As a result, it can be said that teachers in general have insufficient knowledge about mathematical models and mathematical modelling process. On the other hand, preservice teachers, in general, also irresolute about mathematical models and mathematical modelling process just like teachers. The views of the preservice teachers about physical manipulatives and visual presentations such as diagram and number line etc. may be mathematical models average values (for both $\bar{x}=3,84$ ) is higher than others. However, preservice teachers are irresolute mostly about the item related "equations or formulas mathematical modelling" $(\mathrm{M}=2,72)$. Preservice teacher has been irresolute on eleven items of survey. On the other hand, percentage of the preservice teachers who said "I have no idea or I do not know" is changed between $11 \%$ and $27 \%$. As a result, it can be said that preservice teachers have also not sufficient knowledge about mathematical models and mathematical modelling process. When comparing the teachers with preservice teachers it has been specified that participators in both groups are irresolute on the same items and arithmetic average values of preservice teachers are in general lower. Especially it has been found out that participators in both group have not much knowledge about mathematical modelling process but teachers have more knowledge even if just a tad than preservice teachers. Again, the percentage of the preservice teachers who said "I have no idea or I do not know" are more than that of preservice teachers. Between the teachers the thought that visual presentations (maps, scales etc.) may not be mathematical models have presentence between the preservice teachers the thought of equations and formulas may not be mathematical modelling have presentence. The item for which teachers and preservice teachers have the highest percentage and for which teachers and preservice teachers opined that "I have no idea or I do not know" is the item related weather virtual manipulatives are the mathematical modelling or not. In that case, it can be said that both teachers and preservice teachers have insufficient knowledge about "virtual manipulative" concept.

Secondly, independent t-test results about is there any significant difference between views about teachers and preservice teachers about (mathematical) models and mathematical modelling process is presented in Table 10 and interpreted.

Table 10. Independent Group T-Test about Comparison of Teachers and Preservice Teachers

\begin{tabular}{|c|c|c|c|c|c|c|c|}
\hline Survey & Components & Person & $\mathrm{n}$ & $\mathrm{M}$ & $\mathrm{sd}$ & $\mathrm{t}$ & $\mathrm{p}$ \\
\hline \multirow{12}{*}{ Models } & \multirow{2}{*}{ MMR } & Teacher & 63 & 26.0156 & 3.76488 & \multirow{2}{*}{5.062} & \multirow{2}{*}{.392} \\
\hline & & Preservice teacher & 64 & 26.8095 & 6.34456 & & \\
\hline & \multirow{2}{*}{ MER } & Teacher & 63 & 26.1094 & 5.12732 & \multirow{2}{*}{8.144} & \multirow{2}{*}{.087} \\
\hline & & Preservice teacher & 64 & 24.1587 & 7.41447 & & \\
\hline & \multirow{2}{*}{ MET } & Teacher & 63 & 19.0469 & 3.01546 & \multirow{2}{*}{3.987} & \multirow{2}{*}{.375} \\
\hline & & Preservice teacher & 64 & 19.6667 & 4.66974 & & \\
\hline & \multirow{2}{*}{ USM } & Teacher & 63 & 10.5000 & 2.61255 & \multirow{2}{*}{1.086} & \multirow{2}{*}{.281} \\
\hline & & Preservice teacher & 64 & 11.0476 & 3.07135 & & \\
\hline & \multirow{2}{*}{$\mathrm{CNM}$} & Teacher & 63 & 10.7188 & 2.28500 & \multirow{2}{*}{5.571} & \multirow{2}{*}{.387} \\
\hline & & Preservice teacher & 64 & 11.1429 & 3.15644 & & \\
\hline & \multirow{2}{*}{ MS } & Teacher & 63 & 13.9531 & 2.91917 & \multirow{2}{*}{4.264} & \multirow{2}{*}{.939} \\
\hline & & Preservice teacher & 64 & 14.0000 & 3.93085 & & \\
\hline \multirow{4}{*}{$\begin{array}{l}\text { Mathematical models } \\
\text { and modelling process }\end{array}$} & \multirow{2}{*}{ MM } & Teacher & 63 & 25.4127 & 6.24147 & \multirow{2}{*}{8.937} & \multirow{2}{*}{$.013^{*}$} \\
\hline & & Preservice teacher & 64 & 23.1719 & 3.40194 & & \\
\hline & \multirow{2}{*}{ MMP } & Teacher & 63 & 32.8281 & 5.97230 & \multirow{2}{*}{2.698} & \multirow{2}{*}{.595} \\
\hline & & Preservice teacher & 64 & 32.1270 & 8.62759 & & \\
\hline
\end{tabular}

According to the table, there has not been found out a significant difference statistically between the views of the teachers and preservice teachers about models $(t=5.062 ; \mathrm{p}>.05)$, about perceptions of how much a model resembles the object which represents $(t=8.144 ; \mathrm{p}>.05)$, about thoughts what contribution model makes in understanding of an fact $(\mathrm{t}=3.987 ; \mathrm{p}>.05)$, understandings how models can be used except for being descriptive and explanatory ( $t=1.086 ; p>.05)$, views of permanence (continuity) of models $(t=5.571 ; p>.05)$, and views of model samples $(t=4.264 ; p>.05)$. Similarly, there has not been found out a significant difference statistically between the views of the teachers and preservice teachers about mathematical modelling process $(t=2.698 ; p>.05)$, but on the other hand there has been found out a significant difference statistically between the views of teachers and preservice teachers about mathematical models $(\mathrm{t}=8.937 ; \mathrm{p}<.05)$ and the difference is on behalf on the teachers. 
3.2 Third Problem: What is the reason of teachers and preservice teachers requesting benefit from mathematical models, mathematical modelling, mathematical modelling process by their perspectives?

The descriptions about mathematical modelling made by 54 teachers (86\%) and 46 preservice teachers (71\%) and the codes that are created by answers gained are presented in Table 11.

Table 11. Descriptions That Are Made by the Teachers and Preservice Teachers about Mathematical Modelling.

\begin{tabular}{lcc}
\hline Codes & $\mathrm{T}(\mathrm{n})$ & $\mathrm{PT}(\mathrm{n})$ \\
\hline $\begin{array}{l}\text { Concretisation on the visual models to understand abstract mathematical concepts better } \\
\text { Transferring the real life state into mathematical language and the process to express them }\end{array}$ & 13 & 14 \\
mathematically. & 5 \\
Use of concrete objects, forms, diagrams, pictures, materials in understanding of a mathematical & 4 & 9 \\
perception or use them in mathematical teaching & 3 & 5 \\
To express mathematics subjects or an expression by symbols, numbers, form for visuals & 4 & - \\
To express a process and system mathematically namely to make it mathematical & 1 & - \\
Product created for solving a mathematical problem. & 2 & 4 \\
To express problems visually which we have already expressed them orally. & 5 \\
Auxiliary elements in order to explain, visualize or clarify the subjects in mathematics and perceptions. & 7 & - \\
Descriptions of mathematical expressions by using perceptions and language. & 1 \\
Structure or model by which student can envision about a subject. & 1 \\
To express a system by means of using mathematical language. & 1 \\
Making understandable and simple of an unknown thing. & 2 \\
\hline
\end{tabular}

When the descriptions made by the teachers and preservice teachers about mathematical model is examined in Table 11, it has been found out that the teachers made correct and convenient descriptions convenient to literature. Particularly, the expressions of "transferring the real life state into mathematical language and expressing in mathematical" and to express a process and system mathematically namely to make it mathematical" are remarkable. However, less number of teachers and preservice teachers making correct and convenient description indicates that participators have insufficient knowledge about mathematical modelling. Thus, when the frequency values and number of sample is compared it is seen that frequency values in the table is low the percentage values of the teachers and preservice teachers are respectively $86 \%$ and $71 \%$.

The answers about what are the mathematical models are taken from $44(70 \%)$ teachers and $39(60 \%)$ preservice teachers and the codes that are created from the answers are presented at the Table 12.

Table 12. The Views of the Teachers and Preservice Teachers about What Are the Mathematical Models.

\begin{tabular}{llcc}
\hline Codes & & $\mathrm{T}(\mathrm{n})$ & $\mathrm{PT}(\mathrm{n})$ \\
\hline \multirow{2}{*}{ Physical materials } & $\begin{array}{l}\text { Matchsticks, counting plates, number blocks, pattern } \\
\text { blocks, geometry board, abacus, algebraic tiles, algebraic } \\
\text { Scales, cube, cylinder, circle, pyramid, concrete materials }\end{array}$ & \multicolumn{2}{c}{28} \\
& $\begin{array}{l}\text { Virtual manipulatives (learning objects), dynamic software, } \\
\text { Computer aided materials } \\
\text { Materials from daily life }\end{array}$ & 9 & 5 \\
Mathematical structures & Basketball hoop, scales, stove pipes, board & 4 & 3 \\
Visual presentations & Equations, formulas, symbols, forms, tables, & 11 & 3 \\
A minimised of something & Forms, tables, diagrams, concrete visuals & 15 & 3 \\
Daily life problems & Geographical map, world map & 2 & 2 \\
\hline
\end{tabular}

According to the table, most of the teachers and preservice teachers have answered this question with correct, significant and acceptable answers. However, the answers for this question overstep the limit may be arisen from similarity of this question to the survey questions. Although the answers to this question overstep the limit, it has been found out that teachers and preservice teachers could not link the some of the samples with modelling in correct 
form. This indicates that participators in both groups have insufficient knowledge with mathematical models. Thus, the frequency values of both teachers and preservice teachers is the lower value according to the sample and the percentage values of the teachers and preservice teachers are respectively $70 \%$ and $60 \%$.

The descriptions about what is the mathematical modelling process have been gained from 32 teachers (51\%) and 8 preservice teachers $(13 \%)$ and the codes that have been created by the answers are presented at the table 13 .

Table 13. Descriptions of the Teachers and Preservice Teachers about Mathematical Modelling Process.

\begin{tabular}{|c|c|c|}
\hline Codes & $\mathrm{T}(\mathrm{n})$ & $\mathrm{PT}(\mathrm{n})$ \\
\hline $\begin{array}{l}\text { Description of the real life problem, and simplify it, creating a real life problem, transforming the } \\
\text { problem, developing it, and solving it. To interpret the model, verifying it, and using it. }\end{array}$ & 8 & 1 \\
\hline Explanation, indicating, using model, (making contact) . & 4 & 1 \\
\hline Process of describing the problem, interpreting it, using model, (making contact) and evaluation. & 12 & 1 \\
\hline Concretisation from beginning to the end and solution development process. & 1 & - \\
\hline Introduction, developing and results. & 2 & 1 \\
\hline $\begin{array}{l}\text { Designing the material, using it, taking feedback, determining the deficiencies according to the } \\
\text { feedbacks and developing the material. }\end{array}$ & 1 & - \\
\hline $\begin{array}{l}\text { To understand the facts and the problem, simplifying the problem, transferring into the } \\
\text { mathematical environment, process of evaluation of probable solutions. }\end{array}$ & 1 & - \\
\hline $\begin{array}{l}\text { To reveal the form of model and the results of experiments, to determine mathematical expressions } \\
\text { convenient to these results, to write formulas and equations according to these expressions, process } \\
\text { of to make them mathematical. }\end{array}$ & 1 & - \\
\hline Process of mathematical modelling. To make a model easily understandable by making modelling. & 1 & 1 \\
\hline Process of modelling. Selection of the subject. To make preparations, to apply it and to evaluate it. & - & 1 \\
\hline Process of solving mathematical problem and reasoning process. & - & 1 \\
\hline
\end{tabular}

According to the table rarity of teachers and preservice teachers who answers to this question is remarkable. On the other hand, much of the answers are not related with mathematical modelling process but with problem solving process. Very few teachers and preservice teachers gave correct and significant answers about mathematical modelling process. Under the circumstances both teachers and preservice teachers have insufficient information about modelling process. Thus, lower frequency values in the table that have been gained from the views of 32 teachers $(51 \%)$ and 8 preservice teachers $((13 \%)$ displays the truth of the results.

The answers related to the request for benefitting from mathematical modelling have been gained from 57 teachers $(90 \%)$ and 54 preservice teachers (83\%) and the codes that have been gained from answers are presented in Table 14.

Table 14. Teachers and Preservice Teachers' Reasons of Requesting for Benefitting from Mathematical Modelling

\begin{tabular}{lcl}
\hline Codes & T(n) & PT(n) \\
\hline Making easier to make abstract things concretization & 11 & 9 \\
Reflecting real state & 9 & 8 \\
Making information permanent & 6 & 8 \\
Making understanding easier & 7 & 7 \\
Developing the perspective related to visuality & 9 & 6 \\
Making learning easier & 8 & 6 \\
To secure student learning from doing, living and seeing & 2 & 4 \\
Making envisioning easy & 1 & 3 \\
Removing concept mistakes & - & 2 \\
Addressing more than one senses & 2 & 1 \\
Developing problem solving skill & 6 & - \\
\hline
\end{tabular}


According to the results in the Table nearly all teachers and preservice teachers express that they request benefit from mathematical models in mathematics teaching on account of "to make learning and teaching easier, to make them concrete, to make the information permanent, to make understanding easier, to develop perspectives related to visuality, to make envisioning easier, and to address more than one senses". However, just like open-ended questions the teachers and preservice teachers in this question were not able to make sufficient justifications why they have to benefit from mathematical modelling.

\section{Discussion}

There has been found out significant differences statistically between the views of mathematics teachers according to their gender, their thoughts about the contribution of model to understanding any fact, their understandings about how the models can be used except for being descriptive and explanatory and their views about permanence and continuity of the models and it has been detected that all of these differences are on behalf of the female teachers. On the other hand, according to the gender of mathematics teachers there has not been found out significant difference between their views about model samples that have been used about their perceptions about how much a model can resemble the object which represents it, about their views about the contribution that model made in understanding of any fact, how they are used except for being descriptive and explanatory and their views about model samples that have been used. However, it has been found out significant difference statistically between their views about permanence (continuity) of the models and it has been detected that this is on behalf of female preservice teachers. Özay Köse and Gül (2016) in the research they made with biology preservice teachers specified that there was a significant difference in terms of gender variable only between their views about contribution made by model in understanding a fact and this difference is on behalf of the female students. On the other hand, Aslan and Yadigaroğlu (2013) specified that it has not found out a significant difference according to the gender variable in the six dimensions of the same survey related to the models in the study they made with the students. But the results that have been found in this study differ from the existing results. On the other hand, it has been found out that there is not a significant difference statistically between the views about both mathematical models and mathematical process according to the gender of mathematics teachers and preservice teachers. In the research it has been specified that female teachers and preservice teachers have higher averages than that of male teachers and it has been found out that existing significant differences are on behalf of the female teachers. This finding may be related with the way of learning of males and females. Because, in a research that has been made there were differences in the form of learning in terms of genders and female teachers have higher averages than that of male teachers (Çubukçu, 2004). Thus, if the (scientific) models are supposed to be addressed to both visual and bodily senses there would not be surprised to have a difference on behalf of females.

It has not been found out a significant difference statistically between the views of mathematics teachers in different age brackets and experience years related to the models pertinent a model how much resemble the object, views related multi representations, the contribution that model made in understanding a fact, understandings related to how the models can be used except for being descriptive and explanatory, their views about the permanence (continuity) of models and their views about model sample that have been used. In similar way, it has not been found out a significant difference statistically views about mathematical models and mathematical modelling process of the teachers in different age brackets and experience years. These results indicate that the views of the teachers about (mathematical) models and mathematical modelling process have not been fairly changed as long as their ages and experience years increase. The reason of this result is the insufficient knowledge of the teachers related (mathematical) models and mathematical modelling namely their average values related to the views that have been gained and the existence of the teachers who say "I have no idea". There are no much studies in this subject. Schwerdtfeger (2017) in his research could not find a significant difference statistically between the views of elementary school teachers having different experience years related to the mathematical models and modelling process.

It has not found out a significant difference statistically between the views of middle school and high school teachers related the models as being multi representations, their conceptions related how much a model resemble an object, their thoughts related to the contribution that has been made by a model in order to understand a fact, their understandings related how the models can be used except for being descriptive and explanatory, their views related to the permanence or continuity. However, it has been found out a significant difference statistically between their views about the model samples that have been used and it has been specified that the difference is on behalf of the middle school teachers. Similarly, it has been found out a significant difference statistically between the views of mathematics teachers teaching in different school types about both mathematical models usage and mathematical 
modelling process and it has been specified that the difference is on behalf of middle school teachers. The reason of this difference may be arisen that the teachers can establish better relations between daily life and the mathematics subjects or the experiences of the teachers that have had beforehand (Urhan \& Dost, 2016; Yu \& Chang, 2009).

It has not been found out a significant difference statistically about the perceptions of the mathematics teachers in different teaching level (3. and 4. Class) regarding how much a model resembles the object that it resembles, their thoughts about the contribution made by the model in understanding of a fact, views related the permanence of models, their views about model samples that have been used. But it has been found out a significant difference statistically between their views about models as being multi representations and their understandings related how the models can be used except for being descriptive and explanatory and it has been detected that the difference is on behalf of 3.class preservice teachers. Aslan and Yadigaroğlu (2013) in the study they made with science and mathematics training postgraduate students they specified that it has not been found out a significant difference in six dimensions at the same survey according to the education year variables. On the other hand, Özay Köse and Gül (2016) in the study they made with biology preservice teachers they specified that there is only a significant difference between the views about the contribution that has been made by a model in understanding a fact in terms of class level variable and said that the difference is on behalf of the students whose class level increased. However, being the difference on behalf of 3.class preservice teachers but not of 4.class preservice teachers is conflicted with the study made by Özay Köse and Gül (2016). In this context in the end of the interviews made with an academician informally at the department where survey is practised it has been detected that 3.class preservice teachers had earlier training about mathematical modelling but 4.class preservice teachers had not any training in this subject. For this reason, it has been found out that knowledge of the 3.class preservice teachers about this field has been developed positively even if just a tad (Danusso et al., 2010). However, it has not been found out a significant statistically difference between the views of 3.class and 4.class mathematics teachers about both mathematical models and mathematical modelling process.

Both teachers and preservice teachers generally have been impartial and indecisive in nearly one third of survey items related models. It has been found out that teachers and preservice teachers are in general indecisive about how a model can resemble the object to which it represents namely their knowledge is insufficient. The results of the studies in literature (Ergin et al., 2012; Güneş et al., 2004) and the results that have been found out shows similarity. While the teachers are like minded on the statements related many models can be used to express the characteristics of a fact or object they told that they are partly like-minded on other dimensions about models. Similarly, preservice teachers are partly like-minded on participating on the other statements. In this context it has been found out that teachers and preservice teachers show similar distribution, arithmetical average values of the preservice teachers are a bit lower, teachers have better understanding even if just a tad, but it has been detected that both groups have not sufficient knowledge about models. However, it has been found out that teachers and preservice teachers are in general indecisive in their views about mathematical models and mathematical modelling. Teachers opine that physical manipulatives may be mathematical models, but on matter of visual presentations (maps, scales etc.) may be mathematical models they are both indecisive or they said that I have no idea (nearly one fourth). The views of the preservice teachers that average values physical manipulatives, diagrams, number lines etc. visual representation may be mathematical values are higher than the others. However, preservice teachers are generally indecisive on the statement "equations or formulas are mathematical modelling". The view of the visual presentations (maps, scales etc.) may not be mathematical models is predominant in the teachers but on the other hand the view of the preservice teachers about presentations (maps, scales etc.) may not be mathematical models are dominant. When the teachers and preservice teachers compared it has been found out that the participators in both groups are indecisive and arithmetical average values of the preservice teachers are in general lower than the other. Particularly, it has been found out that participators in both groups have insufficient knowledge about mathematical modelling process but the teachers have more knowledge even if just a tad than the other. Percentage of preservice teachers who say "I have no idea or I do not know" is more than that of teachers. The item having the highest percentage about which teachers and preservice teachers opine as "I have no idea or I do not know" is the item about virtual manipulatives may or may not be mathematical modelling. Thus, it can be said that both teachers and preservice teachers have insufficient knowledge related "virtual manipulative" concept. On the other hand, according to the independent group t-test, it has not been found out a significant difference statistically between the views of teachers and preservice teachers about models as being multi representations, perceptions of how much a model can resemble an object, thoughts about the contribution made by the model in understanding of any fact, their understanding how models can be used except for being descriptive and explanatory, their views about the permanence (continuity) of models and their views about the model samples used. Similarly, a significant difference has not been found out between the views of 
the teachers and preservice teachers about mathematical modelling process, but, on the other hand, it has been found out a significant difference statistically and the difference is found out that it is on behalf on the teachers. This may be arisen from the fact that teachers had more experiences about modelling. Schwerdtfeger (2017) in his study could not found out a significant difference statistically between the views of teachers and preservice teachers about mathematical models and modelling process.

Teachers made more descriptions correct and convenient to literature than that of preservice teachers. Particularly, number of teachers who made a convenient description as "transferring real life state into mathematical language and specified as mathematical" is more than that of preservice teachers. However, the lesser number of teachers and preservice teachers who made correct and convenient description indicate that the participators have insufficient knowledge about mathematical modelling description. It has been found out that both teachers and preservice teachers gave significant and acceptable answers to the question of what are the mathematical models. Although there are much answers to this question it has been found out that teachers and preservice teachers could not linked some of the samples with modelling significantly and correctly. Rarity number of teachers and preservice teachers who answered to the question related what is the mathematical modelling process is remarkable. Most of the answers is not related with mathematical modelling process but with problem solving process. Although the problem solving and mathematical modelling process steps are linked with, when we pay regard to Pollak (2003) and Zawojewski (2010) who described the differences between problem solving and mathematical modelling process, it has been found out that the descriptions related mathematical modelling process is not valid. Although the problem solving and mathematical modelling process steps are linked with, when we pay regard to Pollak (2003) and Zawojewski (2010) who described the differences between problem solving and mathematical modelling process, it has been found out that the descriptions related mathematical modelling process is not valid. Very little number of teachers and preservice teachers gave correct and significant answers related with mathematical modelling process. Thus, we can say that the most knowledge of teachers and preservice teachers related is insufficient. Almost all of teachers and preservice teachers said that they wish to use modelling in their teaching. Günbatar and Sarı (2005) expressed that they found practical to use model in the teaching of most teachers. Teachers and preservice teachers expressed that they wanted to benefit from mathematical models $\ln$ mathematics teaching due to the reasons that they make learning and teaching easier, make knowledge lasting, make understanding easier, make perspectives about visuality developed, make envisioning easier, addressing to the more than one senses. Thus, Günbatar and Sarı (2005) made clear that teachers are the instruments securing understanding the abstract concepts, increasing participation in class and making contributions to thinking.

\section{Conclusions and Recommendation}

As a result, views of the teachers and preservice teachers regarding (mathematical) models and mathematical modeling shows differences according to some variables, however, it is not found out most significant differences in the views of the teachers and preservice teachers in regard with these subjects. On the other hand, it has been found out that teachers and preservice teachers have deficiencies related models, mathematical models and the nature of mathematical modelling process, namely they have insufficient knowledge about these matters. Hence, a lot of studies in literature indicate that teachers and preservice teachers in different fields have insufficient and complex knowledge about models, modelling, mathematical models and mathematical modelling process (Danusso et al. 2010; Everett et al., 2009; Justi \& Gilbert, 2003; Smit \& Finegold, 1995; Treagust, 2002; Van Driel \& Verloop, 1999). For this reason, we may say that it would be beneficial for teachers to have in service seminars and for preservice teachers to have theoretical knowledge in order to remove their insufficiency and to improve their knowledge they have.

\section{References}

Acher, A., Arca, M., \& Sanmarti, N. (2007). Modelling as a teaching learning process for understanding materials: A case study in primary education. Science Education, 91, 398-418. https://doi.org/10.1002/sce.20196

Akgün, L., Çiltaş, A., Deniz, D., Çiftçi Z., \& Işık, A. (2013). Primary school mathematics teachers' awareness on mathematical modelling. Adlyaman Üniversitesi Sosyal Bilimler Enstitüsü Dergisi, 6(12), 1-34. https://doi.org/10.14520/adyusbd.410

Aslan, A., \& Yadigaroğlu, M. (2013). The opinions' post-graduate students in science and maths education about model and modelling. Journal of Research in Education and Teaching, 3(1), 187-195.

Berber, N. C., \& Güzel, H. (2009). Perception of science and mathematics forthcoming teachers related with role and goal of models at science. Selçuk Üniversitesi Sosyal Bilimler Enstitüsü Dergisi, 21, 87-97. 
Berry, J., \& Davies, A. (1996). Written reports. In C.R. Haines and S. Dunthorne (Eds.), Mathematics learning and assessment: Sharing innovative practices. London: Arnold.

Berry, J., \& Houston, K. (1995). Mathematical modelling. Edward Arnold: London.

Blomhøj, M., \& Kjeldsen, T. H. (2006). Teaching mathematical modelling through project work: Experiences from an in-service course for upper secondary teachers. Zentralblatt für Didaktik der Mathematik, 38(2), 163-177. https://doi.org/10.1007/BF02655887

Blum, W., \& Feri, R. B. (2009). Mathematical modelling: Can it be taught and learnt? Journal of Mathematical Modelling and Application, 1(1), 45-58.

Borromeo Ferri, R. (2006). Theoretical and empirical differentiations of phases in the modelling process. Zentralblatt für Didaktik der Mathematik, 38(2), 86-95. https://doi.org/10.1007/BF02655883

Bukova Güzel, E. (2016). Matematik eğitiminde matematiksel modelleme. Ankara: Pegem Akademi.

Chan, C. M. E. (2010). Tracing primary 6 pupils' model development within the mathematical modelling process. Journal of Mathematical Modelling and Application, 1(3), 40-57.

Cheng, A. K. (2001). Teaching mathematical modelling in Singapore schools. The Mathematics Educator, 6(1), 63-75.

Christensen, L. B. (2004). Experimental methodology. United States of America: Pearson Education.

Cohen, L., Manion, L., \& Morrison, (2000). Research methods in education (5th ed.). London: Routledge Falmer. https://doi.org/10.4324/9780203224342

Coll, R. K., \& Treagust, D. F. (2003). Investigation of secondary school, undergraduate, and graduate learners' mental models of ionic bonding. Journal of Research in Science Teaching, 40, 464-486. https://doi.org/10.1002/ tea.10085

Çepni, S. (2007). Araştırma ve proje çalı̧̧malarına giriş. Trabzon: Celepler Matbaacılık.

Çökelez, A. (2009). Students' (grade 7-9) ideas on particle concept: Didactical transposition. Hacettepe University Journal of Faculty of Education, 36, 64-75.

Çubukçu, Z. (2005). Öğretmen adaylarının düşünme stillerinin öğrenme biçimlerini tercih etmelerindeki etkisi. Çağdaş Ĕ̈itim Dergisi, 30(324), 22-31.

Danusso, L., Testa, I., \& Vicentini, M. (2010). Improving prospective teachers' knowledge about scientific models and modelling: Design and evaluation of a teacher education intervention. International Journal of Science Education, 32(7), 871-905. https://doi.org/10.1080/09500690902833221

English, L. D. (2006). Mathematical modelling in the primary school: Children's construction of a consumer guide. Educational Studies in Mathematics, 63, 303- 323. https://doi.org/10.1007/s10649-005-9013-1

Erbaş A., Kertil, M., Çetinkaya, B., Çakıroğlu, E., Alacacı, C., \& Baş. S. (2014). Mathematical modelling in mathematics education: Basic concepts and approaches. Educational Sciences: Theory \& Practice, 14(4), 1-21. https://doi.org/10.12738/estp.2014.4.2039

Ergin, İ., Özcan, İ., \& Sarı, M. (2012). Farklı akademik unvanlara sahip fen öğretmenlerinin branşlara göre model ve modelleme hakkındaki görüşleri. Journal of Educational and Instructional Studies in the World, 2(1), 142-159.

Everett, S. A., Otto, C. A., \& Luera, G. R. (2009). Preservice elementary teachers' growth in knowledge of models in a science capstone course. International Journal of Science and Mathematics Education, 7(6), 1201-1225. https:// doi.org/10.1007/s10763-009-9158-y

Galbraith, P., \& Stillman, G. (2006). A framework for identifying student blockages during transitions in the modelling process. Zentralblatt für Didaktik der Mathematik, 38(2), 143-162. https://doi.org/10.1007/BF02655886

Gilbert, J. K., Boulter, C. J., \& Elmer, R. (2000). Positioning models in science education and in design and Technology education. In Gilbert J. K., \& Boulter C. J. (Eds.), Developing models in science education, 3(17), Dordrecht, The Netherlands: Kluwer Academic Publishers. https://doi.org/10.1007/978-94-010-0876-1_1

Gobert, J. D. (2000). A typology of causal models for plate tectonics: Inferential power and barriers to understanding. International Journal of Science Education, 22(9), 937-977. https://doi.org/10.1080/ 095006900416857

Gobert, J. D., \& Buckley, B. C. (2000). Introduction to model-based teaching and learning. International Journal of 
Science Education, 22(9), 891-894. https://doi.org/10.1080/095006900416839

Gould, H. (2013). Teacher's conceptions of mathematical modelling. Published Doctoral Dissertation, Columbia University, New York, US.

Gödek, Y. (2004). The importance of modelling in science education and in teacher education. Hacettepe University Journal of Faculty of Education, 26, 54-61.

Grosslight, L., Unger, C., Jay, E., \& Smith, C. L. (1991). Understanding models and their use in science: Conceptions of middle and high school students and experts. Journal of Research in Science Teaching, 28(9), 799-822. https://doi.org/10.1002/tea.3660280907

Gümüş, İ., Demir, Y., Koçak, E., Kaya, Y., \& Kırıcı, M. (2008). The effects of model-teaching on student's success. Erzincan Eğitim Fakültesi Dergisi, 10(1), 65-90.

Günbatar, S., \& Sarı M (2005). Developing models for difficult and abstract concepts in electrics and magnetism. Gazi Üniversitesi Gazi Eğitim Fakültesi Dergisi, 25(1), 185-197.

Güneş, B., Bağcı, N., \& Gülçiçek, Ç. (2004). Fen bilimlerinde kullanılan modellerle ilgili öğretmen görüşlerinin tespit edilmesi. Abant İzzet Baysal Üniversitesi Eğitim Fakültesi Dergisi, 4(7), 1-14.

Harrison, G. A. (2001). How do teachers and textbook writers model scientific ideas for students? Research in Science Education, 31, 401-435. https://doi.org/10.1023/A:1013120312331

Harrison, G. A., \& Tregaust, F. D. (2000). A typology of science models. International Journal of Science Education, 22(9), 1011-1026. https://doi.org/10.1080/095006900416884

Hıdıroğlu, Ç. N. (2012). Analysing mathematical modelling problems solving processes in the technology-aided environment: An explanation on approaches and thought processes. Published Master Thesis, Dokuz Eylül Üniversitesi, İzmir.

Johnson, R. B., \& Christensen, L. (2014). Educational research: Quantities, qualitative, and mixed approaches (5th ed.). Los Angeles, CA: Sage Publications, Inc.

Justi, R. S., \& Gilbert, J. K. (2003). Teachers' views on the nature of models. International Journal of Science Education, 25(11), 1369-1386. https://doi.org/10.1080/0950069032000070324

Justi, S. R., \& Gilbert, K. J. (2002). Modelling teachers' views on the nature of modelling and implications for the education of modellers. International Journal of Science Education, 24(4), 369-387. https://doi.org/10.1080/09500690110110142

Kaiser, G., Blomhøj, M., \& Sriraman, B. (2006). Towards a didactical theory for mathematical modelling. ZDM, 38(2), 82- 85. https://doi.org/10.1007/BF02655882

Kapur, J. N. (1982). The art of teaching the art of mathematical modelling. International Journal of Mathematic Education in Science and Technology, 13(2), 185-192. https://doi.org/10.1080/0020739820130210

Lee, C. B., Jonassen, D., \& Teo, T. (2011). The role of model building in problem solving and conceptual change. Interactive Learning Environments, 19(3), 247-265. https://doi.org/10.1080/10494820902850158

Lesh, R., \& Doerr, H. M. (2003). Foundations of a models and modelling perspective on mathematics teaching, learning, and problem solving. In R. Lesh, \& H. M. Doerr (Eds.), Beyond constructivism: Models and modelling perspectives on mathematics problem solving, learning, and teaching (pp. 3-33). Mahwah, NJ: Lawrence Erlbaum.

Lingefjärd, T (2006). Faces of mathematical modelling. Zentralblatt für Didaktik der Mathematik, 38(2), 96-112. https://doi.org/10.1007/BF02655884

Maia, P. F., \& Justi, R. (2009). Learning of chemical equilibrium through modelling-based teaching. International Journal of Science Education, 31(5), 603-630. https://doi.org/10.1080/09500690802538045

Márquez, C., Izquierdo, M., \& Espinet, M. (2006). Multimodal science teachers' discourse in modelling the water cycle. Science Education, 90, 202-226. https://doi.org/10.1002/sce.20100

Mason, J. (1988). Modelling: What do we really want pupils to learn? In D. Pimm (Ed.), Mathematics, teachers and children (pp. 201-215). London: Hodder \& Stoughton.

Müller, G. N., \& Wittmann, E. (1984). Der mathematikunterricht in der primarstufe. Braunschweig: Vieweg. https://doi.org/10.1007/978-3-663-12025-4 
National Council of Teachers of Mathematics (NCTM). (1989). Curriculum and evaluation standards for school mathematics. Reston, VA: Author.

National Council of Teachers of Mathematics (NCTM). (2000). Principles and standards for school mathematics. Reston, VA: Author.

O'Connell, S., \& SanGiovanni, J. (2013). Putting the practices into action: Implementing the common core standards for mathematical practice K-8. Portsmouth, New Hampshire: Heinemann.

Örnek, F. (2008). Models in science education: Applications of models in learning and teaching science. International Journal of Environmental \& Science Education, 3(2), 35-45.

Özay Köse, E., \& Gül, Ş. (2006). Prospective biology teachers' understanding of scientific models. Uşak Üniversitesi Sosyal Bilimler Dergisi, 9(3), 162-180.

Peled, I. (2010). (Fish) food for thought: Authority shifts in the interaction between mathematics and reality. Mathematics Education Research Journal, 22(2), 108-120. https://doi.org/10.1007/BF03217569

Pollak, H. O. (2003). A history of the teaching of modelling. In G.M.A. Stanic \& J. Kilpatrick (Eds.), A history of school mathematics, 1, 647 - 671. Reston, VA: NCTM.

Rotbain, Y., Marbach-Ad, G., \& Stavy, R. (2006). Effect of bead and illustration models on high school students' achievement in molecular genetics. Journal of Research in Science Teaching, 43(5), 500-529. https://doi.org/10.1002/tea.20144

Schwerdtfeger, S. (2017). Elementary preservice teachers' and elementary inservice teachers' knowledge of mathematical modelling. Published Doctoral Thesis, Kansas State University, Manhattan, Kansas, US.

Shen, J., \& Confrey, J. (2007). From conceptual change to transformative modelling: A case study of an elementary teacher in learning astronomy. Science Education, 91, 948-966. https://doi.org/10.1002/sce.20224

Smit, J. J. A., \& Finegold, M. (1995). Models in physics: Perceptions held by final-year prospective physical science teachers studying at South African universities. International Journal of Science Education, 17(5), 621-634. https://doi.org/10.1080/0950069950170506

Sriraman, B. (2005). Conceptualizing the notion of model eliciting. In M. Bosch (Ed.), Proceedings of the 4th Congress of the European Society for Research in Mathematics Education CERME 4 (pp. 1686-1696). Spain: Universitat Ramon Llull.

Taylor, I., Barker, M., \& Jones, A. (2003). Promoting mental model building in astronomy education. International Journal of Science Education, 25(10), 1205-1225. https://doi.org/10.1080/0950069022 000017270a

Thomas, K., \& Hart, J. (2010). Pre-service teacher perceptions of model eliciting activities. In R. Lesh et al. (Eds.), Modelling students' mathematical modelling competencies (pp. 531-539). New York, NY: Springer Science \& Business Media.

Treagust, F.D. (2002). Students' understanding of the role of scientific models in learning science. International Journal of Science Education, 24(4), 357-368. https://doi.org/10.1080/09500690110066485

Turkish Ministry of Education. (2005). 6-8th grade mathematics curriculum. Ankara: MEB.

Turkish Ministry of Education. (2013). 9-12th grade mathematics curriculum. Ankara: MEB.

Urhan, S., \& Dost, Ş. (2016). Matematiksel modelleme etkinliklerinin derslerde kullanımı: Öğretmen görüşleri. Elektronik Sosyal Bilimler Dergisi, 15(59), 1279-1295. https://doi.org/10.17755/esosder.263231

Van Driel, H.J., \& Verloop, N. (1999). Teachers' knowledge of models and modelling in science. International Journal of Science Education, 21(11), 1141-1153. https://doi.org/10.1080/095006999290110

Verschaffel, L., Greer, B., \& De Corte, E. (2002). Everyday knowledge and mathematical modelling of school word problems. In K. Gravemeijer, R. Lehrer, B. van Oers \& L. Verschaffel (Eds.), Symbolizing, modelling and tool use in mathematics education (pp. 257-276). Dordrecht, The Netherlands: Kluwer. https://doi.org/10.1007/978-94-017-3194-2_16

Voskoglou, M. G. (2006). The use of mathematical modelling as a tool for learning mathematics. Quaderni di Ricerca in Didattica, 16, 53-60.

Wood, G. (1992). Mathematical modelling in the senior secondary schools: A guide for teachers of senior secondary students. Parkside, South Australia: Mathematical Association of South Australia. 
Yıldırım, A., \& Şimşek. H., (2005). Sosyal bilimlerde nitel araştırma yöntemleri. Ankara: Seçkin Publishing.

Yu, S. Y., \& Chang, C. K. (2009). What did taiwan mathematics teachers think of model-eliciting activities and modelling? In G. Kaiser, W. Blum, R. Borromeo-Ferri \& G. Stillman. (Eds.), Trends in Teaching and Learning of Mathematical Modelling International Perspectives on the Teaching and Learning of Mathematical Modelling (pp. 147-156). New York: Springer.

Zawojewski, J. (2010). Problem solving versus modelling. In R. Lesh, P. Galbraith, C. R. Haines, \& A. Hurford (Eds.), Modelling students' mathematical modelling competencies: ICTMA 13(pp. 237-244). New York: Springer. https://doi.org/10.1007/978-1-4419-0561-1_20 